\title{
Optimalisasi Penyediaan Bibit Rumput Laut Kotonii (Kappaphycus alvarezii) Hasil Kultur Jaringan
}

\author{
[Optimization of supply seeds seaweed cotonii (Kappaphycus alvarezii) \\ result of tissue culture]
}

\author{
Nico Runtuboy, Slamet Abadi
}

Balai Besar Perikanan Budidaya Laut Lampung

Jalan Yos Sudarso, Desa Hanura, Padang Cermin, Kabupaten Pesawaran, Lampung

Diterima: 10 Januari 2018; Disetujui: 9 Maret 2018

\begin{abstract}
Abstrak
Keberhasilan penyediaan bibit rumput laut kotonii (Kappaphycus alvarezii) melalui kultur jaringan, perlu ditindaklanjuti dengan penyebaran bibit rumput laut hasil F1 secara masif dan meluas. Karenanya perlu dilakukan penelitian untuk melihat potensi pengembangan lanjutan bibit rumput laut hsil kultur jaringan ini. Penelitian dilakukan selama empat minggu, yaitu masa umur bibit terbaik; dengan menggunakan berat awal bibit yang sama yaitu 75 gram pada berbagai kedalaman perairan efektif penetrasi sinar matahari. Parameter yang diamati meliputi, laju pertumbuhan harian, dan sintasan. Hasil penelitian memperlihatkan bahwa pada kedalaman efektif penetrasi sinar matahari permukaan tercatat presentasi laju pertumbuhan harian terbaik, yaitu $7,77-10,85 \%$. Semakin kecil penetrasi sinar matahari pada media pertumbuhan bibit, semakin kecil presentasi laju pertumbuhan harian. Sedangkan tingkat kelulusan hidup, tidak memperlihatkan perbedaan, sejauh masih terdapat penetrasi sinar matahari; nilai tingkat kelulusan hidup sama yaitu $100 \%$. Hal ini berarti optimalisasi penyediaan bibit F1 dari hasi kultur jaringan rumput laut katonii, dapat dilakukan secara masif.
\end{abstract}

Kata kunci: bibit rumput laut kotonii; kultur jaringan; penetrasi sinar matahari

\section{Abstract}

The successful supply of kotonii seaweed seeds (Kappaphycus alvarezii) through tissue culture, needs to be followed up with the spread of seeds of seaweed F1 results in a massive and widespread. Therefore it is necessary to do research to see the potential of further development of seaweed seedlings of this tissue culture hsil. The study was conducted for four weeks, namely the best age of seeds; by using the initial weight of the same seeds that is 75 grams at various depths of effective waters of sunlight penetration. Parameters observed included, daily growth rate, and synthesis. The results showed that at the effective depth of surface sunlight penetration recorded the best daily growth rate presentation, that is $7,77-10,85 \%$. The smaller the penetration of sunlight on the growth medium of the seedlings, the smaller the presentation of the daily growth rate. While the level of graduation of life, do not show the difference, as far as there is penetration of sunlight; the same life graduation rate is $100 \%$. This means optimizing the supply of F1 seeds from the katonii seaweed tissue culture, can be done massively

Keywords: kotonii seaweed seedlings; sunlight penetration; tissue culture

Penulis korespondensi

Nico Runtuboy | nicoruntuboy85@yahoo.com 


\section{PENDAHULUAN}

Rumput laut yang termasuk jenis kotonii (Kappaphycus alvarezii) adalah salah satu komoditas andalan perikanan budidaya di Indonesia yang diklaim oleh berbagai pihak, dapat mencapai nilai pasar sebesar 34 US dollar. Pada berbagai kesempatan, Direktur Jenderal Perikanan Budidaya, Slamet Soebjakto mengatakan bahwa upaya optimalisasi pemanfaatan varian jenis rumput laut akan terus didorong, sehingga akan mampu memberikan manfaat nilai ekonomi bagi masyarakat maupun perekonomian nasional. Sebagaimana suatu sistem, maka percepatan pengembangan budidaya rumput laut sangat ditentukan dari ketersediaan bibit yang diunggulkan dalam jumlah besar, masif, tepat waktu dan terjangkau.

Dari sisi teknis budidaya, bisnis penyediaan bibit rumput laut sangat berpotensi untuk didorong segera menggeliat; karena secara teknis metode budidaya mudah, murah, umur panen pendek, panen dan pasca panen sederhana dan menyerap banyak tenaga kerja. Dengan hadirnya bibit rumput laut hasil kultur jaringan, maka langkah berikutnya adalah perbanyakan bibit hasil kultur jaringan dalam tahapan $\mathrm{F} 1 \mathrm{di}$ lapangan. Sejauh ini Balai Besar Budidaya Laut/BBBL Lampung telah melakukan pembuatan kebun bibit secara vegetatif dalam green house selama 2-3 bulan; kemudian juga telah dilanjutkan dengan uji multi-lokasi di beberapa titik, yaitu di wilayah Lampung pada daerah Pahawang, Ketapang, Sragi, Legundi; serta di wilayah Banten pada daerah Lontar. Kegiatan uji multilokasi ternyata memberi hasil yang cukup baik dan tetap berkembang sampai saat ini. Mengantisipasi perkembangan bibit tersebut maka pada tahun 2014, BBPBL Lampung melakukan perekayasaan perbanyakan bibit rumput laut kotoni (Kappaphycus alvarezii) hasil kultur jaringan secara semi masal.

Tujuan penelitian ini adalah untuk mendapatkan data tentang kedalaman yang ideal untuk perkembangan bibit rumput laut hasil kultur jaringan. Diharapkan hasil penelitian dapat memberi informasi yang tepat tentang kedalaman yang ideal untuk kegiatan membudidayakan rumput laut kotoni hasil kultur jaringan.

\section{BAHAN DAN METODE}

Penelitian ini dilakukan di Balai Besar Perikanan Budidaya Laut Lampung pada tahun 2015 selama empat minggu. Bahan penelitian adalah bibit hasil kultur jaringan yang berasal dari Southeast Asian Regional Centre for Tropical Biology (SEAMEO BIOTROP) di Bogor; yang telah diaklimatisasi di green house BBBL Lampung sebagai $F 1$, berasal dari jenis: Kappaphycus alvarezii. rumput laut 
kotonii dengan kriteria: (a) umur panen 25 hari; (b) bercabang banyak dan rimbun; (c) thalus mulus (tidak terkelupas); (d) masih segar; dan (e) ujung thalus runcing. Jumlah berat awal bibit yang digunakan dalam penelitian ini, sebesar 75 gram. Metode penelitian yang digunakan adalah metode eksperimental disain. Rancangan percobaan dari penelitian ini adalah Rancangan Acak Lengkap (RAL) meliputi tiga perlakuan penetrasi sinar matahari: Perlakuan A (penetrasi sinar matahari permukaan/10 $\mathrm{cm}$ ), $\quad B$ (penetrasi sinar matahari pertengahan $/ 30 \mathrm{~cm}$ ) dan $C$ (penetrasi sinar matahari terdalam $/ 50 \mathrm{~cm}$ ). Masingmasing perlakuan dengan 3 kali pengulangan. Metode budidaya dalam penelitian ini yang digunakan adalah metode rakit bambu apung ukutan $3 \times 5 \mathrm{~m}$ sebanyak satu unit dengan tiga perlakuan penetrasi sinar matahari dan tiga ulangan (Gambar 1.). Sedangkan tali jalur yang digunakan adalah tali dari bahan PE $4 \mathrm{~mm}$ untuk mengikat bibit rumput laut. Salah satu faktor yang berpengaruh terhadap pertumbuhan rumput laut Eucheuma cottonii yang dibudidayakan adalah bobot awal. Kontrol dilakukan selama penelitian dilakukan setiap hari sebagai tindakan preventif untuk mencegah adanya serangan ikan herbivora seperti ikan Baronang dan penyu. Selain untuk tindakan preventif, kegiatan pengontrolan dilakukan untuk membersihkan tanaman dari tanaman pengganggu, merawat konstruksi maupun tanaman uji. Parameter utama yang diamati adalah presentase laju pertumbuhan harian (pertambuhan berat), dan sintasan (SR); demikian juga dilakukan pengamatan terhadap kualitas air setiap minggu. Untuk mengetahui perkembangan tanaman maka dilakukan sampling pertumbuhan setiap minggu. Kegiatan sampling dilakukan dengan cara mengangkat semua tanaman untuk diukur.

- Untuk mengetahui laju presentase pertumbuhan harian rumput laut digunakan rumus:

$$
a=\left\{\left[W_{t} / W_{0}\right]^{1 / t}-1\right\} \times 100 \%
$$

dimana :

a = laju pertumbuhan harian (\%)

$\mathrm{W}_{\mathrm{t}}=$ berat individu rata-rata $(\mathrm{gram})$

$\mathrm{W}_{\mathrm{o}}=$ berat individu awal penebaran $(\mathrm{g})$

$\mathrm{t} \quad=$ waktu

- Untuk mengetahui tingkat kelulusan hidup digunakan rumus :

$$
\text { SR }(\%)=\frac{\sum \mathrm{t}}{\sum 0} \times 100 \%
$$

dimana :

$\mathrm{SR}=$ tingkat kelulusan hidup (\%)

$\sum t=$ jumlah populasi akhir (gram)

$\sum 0=$ jumlah populasi awal (gram) 
Kegiatan sampling dilakukan secepat mungkin pada pagi hari di tempat yang terlindung dari sinar matahari langsung; guna menghindari kerusakan rumput laut uji dari terpaan sinar matahari.

\section{HASIL DAN PEMBAHASAN}

Hasil

Hasil pengamatan kualitas air pada penelitian selama empat minggu, dapat dilihat pada Tabel 1. Hasil laju presentase pertumbuhan harian rumput laut kotonii selama empat minggu dapat dilihat pada Tabel 2.; sedangkan tingkat kelulusan hidup rumput laut kotonii

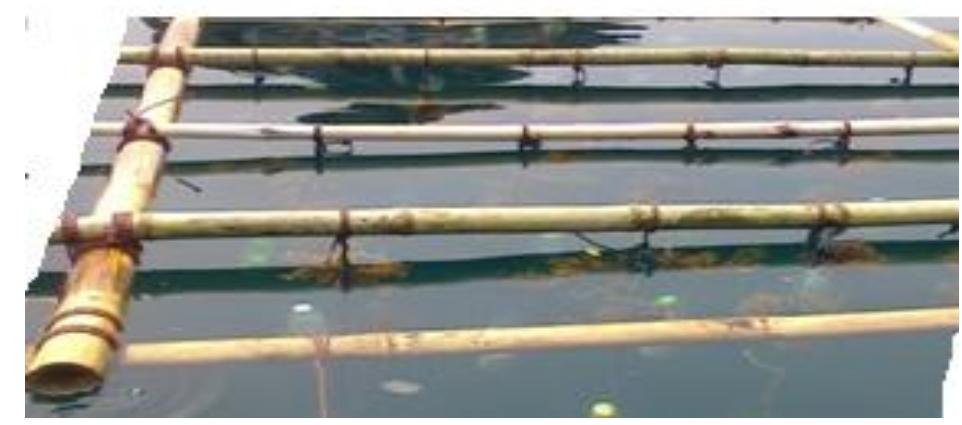

Gambar 1. Rakit bambu wadah penelitian bibit rumput laut

Tabel 1. Hasil pengamatan kualitas air di lokasi penelitian

\begin{tabular}{clccccc}
\hline No & Parameter & Satuan & Mg I & Mg II & Mg III & Mg IV \\
\hline 1. & Salinitas & ppt & 28 & 28 & 30 & 30 \\
2. & pH & - & 7,88 & 8.00 & 7.89 & 8.00 \\
3. & Suhu air & ${ }^{0} \mathrm{C}$ & 23 & 25 & 27 & 30 \\
4. & Kecerahan & $\mathrm{m}$ & 3 & 3,5 & 4 & 5 \\
5. & Kecepatan arus & $\mathrm{cm}^{-\mathrm{dtk}^{-1}}$ & 20 & 25 & 30 & 30 \\
6. & Oksigen terlarut & $\mathrm{ppm}$ & 6,2 & 5,0 & 4,3 & 4,5 \\
\hline
\end{tabular}

Tabel 2. Hasil laju persentase pertumbuhan harian selama penelitian

\begin{tabular}{|c|c|c|c|c|c|}
\hline \multirow{2}{*}{ No } & \multirow{2}{*}{ Perlakuan } & \multicolumn{4}{|c|}{ Minggu ke- (\%) } \\
\hline & & I & II & III & IV \\
\hline 1. & $\begin{array}{l}\text { Penetrasi sinar matahari } \\
\text { permukaan } / 10 \mathrm{~cm}\end{array}$ & 7,77 & 7,84 & 8,95 & 10,85 \\
\hline 2. & $\begin{array}{l}\text { Penetrasi sinar matahari } \\
\text { pertengahan } / 30 \mathrm{~cm}\end{array}$ & 8,30 & 6,17 & 7,87 & 8,52 \\
\hline 3. & $\begin{array}{l}\text { Penetrasi sinar matahari } \\
\text { terdalam } / 50 \mathrm{~cm}\end{array}$ & 4,11 & 4,51 & 5,33 & 6,28 \\
\hline
\end{tabular}


Tabel 3. Hasil tingkat kelulusan hidup selama penelitian

\begin{tabular}{llcccc}
\hline \multirow{2}{*}{ No } & \multicolumn{1}{c}{ Perlakuan } & \multicolumn{4}{c}{ Minggu ke- (\%) } \\
\cline { 2 - 6 } & \multicolumn{1}{c}{ I } & II & III & IV \\
\hline 1. & $\begin{array}{l}\text { Penetrasi sinar matahari } \\
\text { permukaan } / 10 \mathrm{~cm}\end{array}$ & 100 & 100 & 100 & 100 \\
2. & $\begin{array}{l}\text { Penetrasi sinar matahari } \\
\text { pertengahan } / 30 \mathrm{~cm}\end{array}$ & 100 & 100 & 100 & 100 \\
3. & $\begin{array}{l}\text { Penetrasi sinar matahari } \\
\text { terdalam } / 50 \mathrm{~cm}\end{array}$ & 100 & 100 & 100 & 100 \\
\hline
\end{tabular}

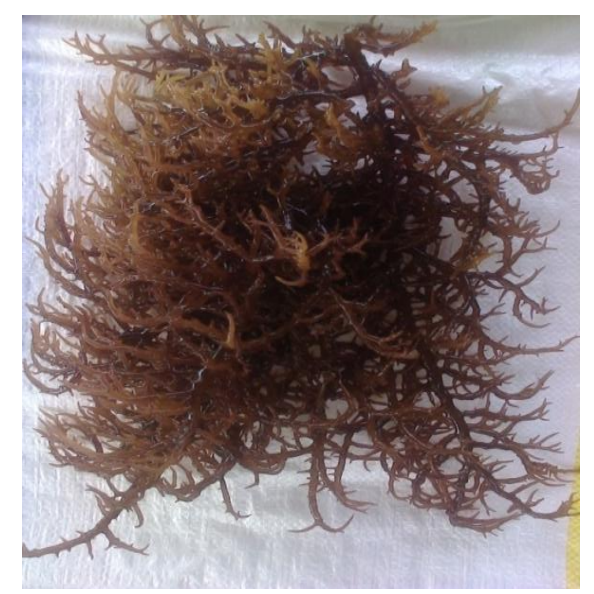

Gambar 2. Hasil panen penelitian budidaya Kappaphycus alvarezii

selama penelitian dapat dilihat pada Tabel 3. Hasil panen rumput laut dapat dilihat pada Gambar 2.

\section{PEMBAHASAN}

Kualitas Air

Hasil pengamatan parameter kualitas air pada penelitian selama empat minggu, dapat dilihat pada Tabel 1. Air merupakan media tempat hidup rumput laut tersebut sehingga selama masa uji coba juga dilakukan pengamatan setiap minggu terhadap lima parameter kunci yang berpengaruh terhadap perkembangan rumput laut. Faktor fisik meliputi gerakan air yang disebabkan oleh suhu air dan kecepatan arus. Hasil pantauan selama penelitian memperlihatkan suhu perairan berada pada kisaran 23-30 ํ․ Menurut Muñoz et al. (2004), suhu air laut yang berkisar antara 28-31 ${ }^{\circ} \mathrm{C}$, dengan rentang fluktuasi harian antara 25,9 dan $31,9^{\circ} \mathrm{C}$; akan cukup mendukung pertumbuhan cottonii.

Kondisi suhu air laut yang cukup mendukung untuk pertumbuhan optimal rumput laut Kappaphycus alvarezii juga dikemukakan Kasim \& Mustafa (2017) berkisar antara 25-31 ํC. Sedangkan data Standar Nasional Indonesia (SNI) Nomor 01-6492.1-2000 untuk budidaya rumput laut Kappaphycus alvarezii, 
mempersyaratkan suhu air laut optimal pada kisaran 25-30 ํ․ Sehingga dengan demikian, dapat diyakini bahwa selama penelitian, suhu perairan cukup optimal guna mendukung pertumbuhan Kappaphycus alvarezii; walaupun fluktuasi suhu air laut mingguan memperlihatkan kecenderungan yang meningkat dengan berjalannya lama waktu penelitian (lihat Tabel 1.)

Hasil pantauan kecepatan arus selama penelitian berada pada kisaran 20-30 $\mathrm{cm}^{\text {detik }}{ }^{-1}$. Beberapa kajian memperlihatkan data kecepatan arus berkorelasi positif dengan pertumbuhan Kappaphycus alvarezii (Kasim \& Mustafa 2017, Hayashi et al. 2007). Penanganan kondisi perairan untuk mendukung pertumbuhan Kappaphycus alvarezii yang optimal, ternyata juga dikemukakan Hurtado \& Critchley (2018) yang menyatakan bahwa perlu ada upaya untuk meningkatkan toleransi terhadap stres pada rumput laut Kappaphycus alvarezii agar memperoleh produktivitas yang lebih tinggi dan karakteristik kualitas yang juga meningkatkan (yaitu, paparan peningkatan suhu permukaan air laut, fluktuasi salinitas dan iradiasi foto-penghambatan serta serangan oleh organisme patogenik dan oportunistik). Menurut Direktorat Jenderal Perikanan Budidaya (2004), serta Mubarak 1982 dalam Wisnu Aryati (2007), menjelaskan bahwa bahwa kecepatan arus laut yang dianjurkan untuk budidaya rumput laut berkisar 20-40 cm.detik ${ }^{-1}$. Dengan kecepatan arus seperti ini, rumput laut dapat dibersihkan dari kotoran dan mendapat suplai nutrien dengan optimal. Kisaran arus laut di lokasi penelitian, masih berada dalam kisaran yang dianjurkan. Dengan demikian dapat dikatakan bahwa kondisi kecepatan arus saat penelitian selama ini, cukup menunjang pertumbuhan Kappaphycus alvarezii.

Kajian Susilowati et al. (2012) juga menyatakan bahwa pertumbuhan rumput laut yang dibudidayakan di areal permukaan perairan laut ternyata lebih cepat, karena penetrasi sinar matahari cukup tinggi yang dipengaruhi oleh kecerahan air laut. Lebih lanjut Sunarto (2008) dalam Susilowati et al. (2012) mengemukakan bahwa fotosintesis akan bertambah sejalan dengan peningkatan intensitas cahaya pada suatu nilai optimum tertentu (cahaya saturasi). Intensitas cahaya juga akan berkaitan langsung dengan produktivitas primer suatu perairan, semakin tinggi intensitas suatu cahaya maka semakin tinggi pula produktivitas primer pada suatu batasan tertentu. Hasil kajian Akib et al. (2015) menyampaikan kecerahan perairan di zona pemanfaatan budidaya rumput laut, Eucheuma cottoni di Pulau Selayar, Sulawesi Selatan berada para kisaran antara 2,04 sampai $6.09 \mathrm{~m}$; cukup untuk 
mendukung produktivitas rumpu laut. Kajian Radiarta (2016) menambahkan, sehubungan dengan hal kecerahan; maka dari hasil kajiannya menyimpulkan bahwa bulan produktif untuk budidaya rumput laut di peraiaran Indonesia khususnya di Sulawesi Utara adalah sekitar bulan Oktober-Juni. Data lapangan menunjukkan, nilai kecerahan pada lokasi penelitian berada pada kisaran 3-5 m; yang memberi keyakinan bahwa nilai kecerahan perairan lokasi penelitian dipandang cukup mendukung optimalisasi pertumbuhan rumput laut.

Nilai Salinitas, $\mathrm{pH}$ dan kandungan oksigen terlarut pada lokasi penelitian, sebagaimana terlihat pada Tabel 1.; secara umum tampak dapat mendukung persyaratan yang minimal pertumbuhan Kappaphycus alvarezii (SNI Nomor 016492.1-2000)

\section{Laju Pertumbuhan dan Tingkat Kelulusan Hidup.}

Hasil pengamatan parameter laju pertumbuhan harian dapat dilihat pada Tabel 2; dan tingkat kelulusan hidup pada dilihat pada Tabel 3. Tampilan Kappaphycus alvarezii di akhir penelitian dapat dilihat pada Gambar 2. Data hasil pengamatan pada perlakuan penetrasi dari sinar matahari dekat permukaan atau $10 \mathrm{~cm}$, memperlihatkan persentasi untuk laju pertumbuhan harian yang lebih tinggi yaitu antara 7,77 sampai $10,85 \%$; dibanding dua perlakuan lainnya, yaitu antara 6,17 sampai $8,52 \%$ pada perlakuan penetrasi sinar matahari pertengahan $/ 30 \mathrm{~cm}$; serta antara 4,11 sampai 6,28\% pada perlakuan penetrasi sinar matahari terdalam $/ 50 \mathrm{~cm}$. Kajian lain juga memperlihatkan pada laju pertumbuhan harian yang serupa 5.27.2\% per-hari (Susilowati et al. 2012); pertumbuhan populasi akhir meningkat $600 \%$ dari bobot awal tanam (Radiarta 2016).

Untuk mendapatkan hasil kultur jaringan pada regenerasi Kappaphycus alvarezii yang cukup baik, menurut Mulyaningrum (2012) Formulasi zat ZPT indole acetic acid (IAA) : kinetin : zeatin, dengan konsentrasi yang sesuai merupakan faktor yang menentukan regenerasi filamen talus menjadi tunas. Lebih lanjut kajian Mulyaningrum (2012) menyakan bahwa pada media air yang diberikan formulasi ZPT indole acetic acid (IAA): kinetin: zeatin. senilai (0,4:0:1) ppm menunjukkan laju pertumbuhan harian $1,929 \%$. $^{-1}$ iri $^{-1}$, sintasan $83,33 \%$, kecepatan regenerasi $41,67 \%$ dan ratarata panjang tunas 44,59 $\mu \mathrm{m}$. Tunas mulai terbentuk pada 15 hari masa kultur. Selain perolehan hasil kultur jaringan Kappaphycus alvarezii, kajian dari Daud et al. (2012) menyampaikan agar dapat memperkuat vitalitas hasil kultur jaringan ini dengan ketahanan terhadap penyakit ice-ice. Saran Daud et al. (2012) sebagai bagian dari hasil kajian tentang hal ini 
adalah penggunaan bahan asam sitrat sebagai pengkelat logam berat. Introduksi gen sitrat sintase ke dalam genom Kappaphycus alvarezii diketahui dapat mengurangi cekaman oksidatif; yang dapat memberikan efisiensi regenerasi tunas transgenik putatif sebesar $100 \%$, efisiensi tunas non transgenik sebesar $100 \%$.

Beberapa keunggulan lainnya menggunakan bibit rumput laut hasil kultur jaringan memiliki, antara lain melalui induksi kalus dan embrio dengan penambahan hormon pertumbuhan yang diintroduksi ke dalam media kultur yang dapat memacu induksi kalus dan penebalan pigmen rumput laut; dan juga memiliki kandungan keragenan yang lebih tinggi untuk bibit hasil kultur jaringan (40,7-44,1\%) dibanding menggunakan bibit hasil pemotongan (33,0-36,9\%), serta bibit rumput laut asal dari kultur jaringan adalah cara untuk memilih strain terbaik dari Kappaphycus alvarezii. Bahkan catatan dari beberapa lokasi memperlihatkan catatan bahwa kecepatan tumbuh rumput laut yang menggunakan bibit hasil kultur jaringan adalah 1,5-1,8 kali jauh lebih cepat pertumbuhan, dibanding yang dilakukan selama ini oleh pembudidaya. Diyakini kedepan, teknik mikropropagasi ini dapat memberikan sistem alternatif yang berguna untuk produksi massal bibit rumput laut yang penting secara ekonomi
(Reddy et al. 2002, Sulistiani et al. 2011, Hayashi et al. 2012, Suryati \& Mulyaningrum 2012, Yeong et al. 2013). Persentase laju pertumbuhan harian Kappaphycus alvarezii selama penelitian memperlihat pertambahan berat dengan kecenderungan meningkat dengan meningkatnya lama waktu pemeliharaan. Delta persentase laju pertumbuhan harian dari minggu ke-2 $(0,07 \%)$ menuju minggu ke-3 (1,11\%) tercatat rata-rata lebih tinggi dibanding persentase laju pertumbuhan harian pada minggu lainnya. Hal ini berarti, persentase laku pertumbuhan harian yang optimal terjadi pada minggu ke-3. Dan sebagaimana pola pertumbuhan biota perairan yang juga memiliki kecenderungan adanya pertambahan berat yang menurun ("diminishing return"); maka dapat dilakukan pemanen untuk benih dari hasil pemotongan, bila diperlukan pada akhir minggu ke-3 dari masa pemeliharaan dengan menggunakan bibit hasil kultur jaringan

\section{SIMPULAN}

Berdasarkan hasil penelitian optimalisasi penyediaan bibit rumput laut (Kappaphycus alvarezii) hasil kultur jaringan berdasarkan penetrasi sinar matahari, maka simpulan yang diambil adalah:

a. Pada penetrasi sinar matahari permukaan $/ 10 \mathrm{~cm}$, persentase laju 
pertumbuhan harian adalah yang terbaik, yaitu antara $7,77 \%$ sampai $10,85 \%$ atau dengan nilai rata-rata $8,84 \%$;

b. Pada tingkat kelulusan hidup (SR) dari semua perlakuan tercatat sangat tinggi yaitu $100 \%$.

\section{PERSANTUNAN}

Ucapan terima kasih disampaikan kepada Kepala Balai Besar Budidaya Laut Lampung atas fasilitasi yang diberikan untuk melakukan penelitian ini.

\section{DAFTAR PUSTAKA}

Akib A, M Litaay, Ambeng, M Asnady. 2015. Kelayakan kualitas air untuk kawasan budidaya Eucheuma cottoni berdasarkan aspek fisika, kimia dan biologi di Kabupaten Kepulauan Selayar. Jurnal Pesisir dan Laut Tropis 1(1): 25-36

Daud RF, U Widyastuti, S Suharsono, E Suryati, A Parenrengi. 2013. Introduksi gen sitrat sintase ke dalam rumput laut Kappaphycus alvarezii menggunakan agrobacterium tumefaciens, Jurnal Riset Akuakultur 8(2): 2013.

Direktorat Jenderal Perikanan Budidaya. 2008. Petunjuk Teknis Budidaya Laut: Rumput Laut Eucheuma spp. Departemen Kelautan dan Perikanan. Jakarta
Hayashi L, Eurico C. Oliveira, Genevieve B Lhonneur. 2007. The effects of selected cultivation conditions on the carrageenan characteristics of Kappaphycus alvarezii (Rhodophyta, Solieriaceae) in Ubatuba Bay, São Paulo, Brazil. Journal of Applied Phycology, October 2007.

Hayashi L, NS Yokoya, DM Kikuchi, EC Oliveira. 2007. Callus induction and micropropagation improved by colchicine and phytoregulators in Kappaphycus alvarezii (Rhodophyta, Solieriaceae). Journal of Applied Phycology 20(5): 653-659.

Hurtado AQ, AT Critchley. 2018. A review of multiple biostimulant and bioeffector benefits of AMPEP, an extract of the brown alga Ascophyllum nodosum, as applied to the enhanced cultivation and micropropagation of the commercially important red algal carrageenophyte Kappaphycus alvarezii and its selected cultivars. in 6th Congress of the International Society for Applied Phycology.

Kasim M, A Mustafa. 2017. Comparison growth of Kappaphycus alvarezii (Rhodophyta, Solieriaceae) cultivation in floating cage and longline in Indonesia. Aquaculture Report 6 (2017): 49-55. journal 
homepage: www.elsevier.com/ locate/aqrep

Mulyaningrum SRH, H Nursyam, $\mathrm{Y}$ Risjani, A Parenrengi. 2012. Regenerasi filamen kalus rumput laut Kappaphycus alvarezii dengan formulasi zat pengatur tumbuh yang berbeda. Jurnal Penelitian Perikanan 1(1); tahun 2010

Muñoz J, Yolanda F Pelegrín, D Robledo. 2004. Mariculture of Kappaphycus alvarezii (Rhodophyta, Solieriaceae) color strains in tropical waters of Yucatán, México. Journal Aquaculture 239 (1-4): 161-177. September 2004.

Suryati E, SRH Mulyaningrum. 2009. Regenerasi rumput laut Kappaphycus alvarezii (doty) melalui induksi kalus dan embrio dengan penambahan hormon perangsang tumbuh secara in vitro. Jurnal Riset Akuakultur 4 (1): tahun 2009.

Susilowati T, Sri Rejeki, Eko Nurcahya Dewi, Zulfitriani. 2012. Pengaruh kedalaman terhadap pertumbuhan rumput laut (Eucheuma cottonii) yang dibudidayakan dengan metode longline di Pantai Mlonggo, Kabupaten Jepara. Jurnal Saintek Perikanan 8 (1): tahun 2012.

Sulistiani E, D. T. Soelistyowati, S. A. Yani, H.Affandi. 2012.
Acclimatization and field cultivation of regenerated cottonii seaweed (Kappaphycus alvarezii Doty) from tissue culture in coastal waters. Technical Report SEAMEO BIOTROP. Published 2012. 